Bond University

Research Repository

\title{
Keys to success in social media marketing (SMM) - Prospects for the German airline industry
}

Knoblich, Stephan; Martin, Andrew; Nash, Robert; Stansbie, Paul

Published in:

Tourism and Hospitality Research

DOI:

$10.1177 / 1467358415610415$

Licence:

Other

Link to output in Bond University research repository.

Recommended citation(APA):

Knoblich, S., Martin, A., Nash, R., \& Stansbie, P. (2017). Keys to success in social media marketing (SMM) Prospects for the German airline industry. Tourism and Hospitality Research, 17(2), 147-164.

https://doi.org/10.1177/1467358415610415

\section{General rights}

Copyright and moral rights for the publications made accessible in the public portal are retained by the authors and/or other copyright owners and it is a condition of accessing publications that users recognise and abide by the legal requirements associated with these rights.

For more information, or if you believe that this document breaches copyright, please contact the Bond University research repository coordinator. 
Keys to success in Social Media Marketing (SMM) - Prospects for the German Airline Industry 


\section{Keywords:}

\section{Social Media, Marketing, German airline industry, User generated content}

\section{Introduction}

Global aviation represents one of the most important and fastest growing industries, having recently recorded an enlargement of approximately 5\% over the past two decades (Vespermann \& Wittmer, 2010). Without doubt "air transport lies at the heart of global business" and allows consumers to travel quickly, conveniently, and for affordable prices (Oxford Economics, 2011, p.1). When set in the context of a highly technologically developed country like Germany, air transportation becomes an even more important contributor to the nation's economic growth and its wealth (BMWi, 2009; Euromonitor International, 2011). Air traffic ensures Germany’s success as a business location and as a prime export economy (BDI DATE) Further support is offered by the International Air Transportation Association's CEO, Tony Tyler, when stating that "Germany plays a key role in the European economy (and that) aviation connectivity is critical to Germany’s economic success” (BDL, 2012).

The size of that contribution is evidenced by an overall turnover of approximately $€ 63$ billion, with the German aviation sector accounting for $2.6 \%$ of the national GDP. Further, the German airline industry’s economic footprint generates a significant Gross Value Added of $€ 47.9$ billion and offers approximately 816,000 people an occupation (Oxford Economics, 2011). In 2018 the German airlines industry is forecast to have a value of \$29 813.2 million, an increase of $15.7 \%$ since 2013. Although the German airlines industry experienced a contraction of $0.7 \%$ of passenger numbers in 2013, the forecast for 2018 is 106 million passengers, an increase of 4.9\% on 2013. (MarketLine May 2014). These numbers provide information on the importance and vital role of the airline industry as a major contributor to the domestic economy as well as demonstrating the sector's relevance as a mode of transportation (BMWi, 2009; DLR, 2009). Moreover, German airlines’ success also positively impacts the German tourism and leisure 
industry. Likewise, this catalytic effect contributes to the domestic GDP and generates approximately $€ 13$ billion of foreign visitors’ spending for air travelling each year (Oxford Economics, 2011). In order to maintain this prosperity in the highly competitive global marketplace, German airlines are forced to examine and adopt contemporary marketing practices to effectively promote their brand, products, and services to both business and leisure travellers. This evolution in marketing strategy becomes essential in a segmented business sector like the tourism industry where the latest marketing practices are orientated around helping to increase customer engagement and loyalty in a technologically connected world (Constantinides \& Fountain, 2008; Hettler, 2010; Hill \& Moran, 2011).

To that end, latest technological communication innovations have led to a shift away from traditional marketing concepts towards a more contemporary marketing paradigm, which is often referred to as 'new media marketing' or 'consumer generated media'. This contemporary phenomenon makes use of the basic principles of the traditional marketing concepts, but enlarges these to a more customer-focused, interactive and electronically based messaging, so called Social Media (SM) (Mangold \& Faulds, 2009; Winer, 2009). The rise of Web 2.0 and SM (i.e. an extension of Web 2.0) has augmented, but not completely replaced, "the set of communication tools that marketers had used for 50-100 years: television, radio, print (magazines, newspaper) and outdoor advertisement” (Winer 2009, p.108). Harris and Rae (2009) investigated the use of the, then, new technologies such as Web 2.0 by entrepreneurial businesses in London and concluded that social networks will play a key role in the future of marketing; replacing customer annoyance with engagement. The key to success with such positive engagement is the quality of content, a requirement for success returned to later. The global outspread of these new communication concepts as well as the on-going digitalisation of media have resulted in more diverse and infinite marketing practices, which have also evoked an “improve(d) marketing efficiency” for tourism enterprises (Ye et al., 2011, p.638). This rapid growth of new media has resulted in the appearance of multiple SM-channels (Figure 1), which 
allow consumers to gather, communicate, collaborate and share content by utilising latest technological innovations and applications (Kane et al., 2009). There is, however, a gap in this area of research in that there is only limited information on the use of SMM-practices as an influential information source for global German aviation enterprises. The practical deficiency of SMM- activities has been identified by Kim (2008), who recognises that many organisations have observed and understood the prevailing SM- phenomenon, but some of them still have not managed to exploit this trend for corporate marketing purposes.

Social media marketing is distinct from social media advertising in that it is driven by (and therefore success depends on) social engagement (Hanna et al, 2011), resulting in earned media as opposed to paid media (Campbell et al, 2014). Since the term SMM represents a relatively new concept, a review of relevant literature recognises “a lack of a formal definition” (Xiang \& Gretzel 2010, p.180). Although some researchers, (Constantinides \& Fountain, 2008; Mangold \& Faulds, 2009; Kaplan \& Haenlein, 2010 and Weinberg, 2009), agree that SMM refers to the two components of SM and (online) marketing, the expressions user generated content (UGC), “Social Media and Web 2.0” are often used interchangeably, so that no universal definition can be formulated (Constantinides \& Fountain, 2008, p.232).

Many scholars emphasise today’s relevance of SMM as a new marketing paradigm (e.g. Evans (2010), Hettler (2010), Kaplan and Haenlein (2011), Mangold and Faulds (2009), Safko and Brake (2009), Weinberg (2009), Zarella (2010). Yet, there is only limited information on the use and effect of SMM-practices as an influential information source for global, or in particular, for German aviation enterprises. The practical deficiency of SMM- activities has also been identified by Kim (2008), who recognises that many organisations have observed and understood the prevailing SM- phenomenon, but some of them still have not mastered to leverage this trend for corporate marketing purposes. Therefore, motivated by the relevance of SMM and the gap in literature, it is necessary to identify, in which ways German airline organisations have implemented SM as a marketing tool. Moreover, this raises the issue of 
consumer sentiments towards SMM; i.e. in how far new marketing tools affect customer loyalty, brand awareness, brand exposure, as well as consumers purchasing decisions.

Motivated by the contemporary relevance of SMM and the identified gap in literature, the purpose of this research is to identify factors of success for business to consumer communication in Social Media Marketing and to determine consumer's perceptions in regard to identified social media engagement in German airlines. In doing so, the research objectives will specifically examine key concepts of SMM and contextualise their role and importance as a contemporary marketing tool. In addition, the paper will outline the keys to success as it relates to the use of SMM within German airline organisations.

\section{Literature Review}

\subsection{Definition}

Since the term SMM represents a relatively new concept, a review of relevant and current literature recognises “a lack of a formal definition” (Xiang and Gretzel 2010, p.180). Although many scholars, e.g. Constantinides and Fountain (2008), Mangold and Faulds (2009), Kaplan and Haenlein (2010) and Weinberg (2009), agree that SMM refers to the two components of SM and (online) marketing, the expressions user generated content (UGC), "Social Media and Web 2.0" are often used interchangeably, so that no universal definition can be formulated (Constantinides and Fountain 2008, p.232). However, to avoid misconceptions, this research uses the definitions of the key variables Web 2.0, SM, UGC and marketing in order to classify the core concept of SMM in more depth.

According to Constandinides and Fountain (2008, p.232), the terminology Web 2.0 is best described as "open-source, interactive and user controlled online applications (that are) expanding the experiences, knowledge and market power of users as participants in business and social processes”. This is supported by Kaplan and Haenlein (2010, p.60), who claim that Web 2.0 represents an ideological and technical platform, “in which software developers and 
end-users (...) utilize the World Wide Web (...) as a platform whereby content and applications are no longer created and published by individuals, but instead are continuously modified by all users in a participatory and collaborative fashion”. In comparison, Social Media comprises all networks and media, which enable social interaction within Web 2.0. For this reason SM encompasses all "activities, practices, and behaviours among communities of people who gather online to share information, knowledge, and opinions using conversational data (e.g. words, pictures, videos, audios) (Safko and Brake 2009, p.6). As stated by Blackshaw and Nazzaro (cited in Xiang and Gretzel 2010, p.180), this data is used with the intention to educate other community members about "products, brands, services and issues". Thus, SM is basically concerned with sharing information, opinions and experiences (i.e. UGC) through Internet-based applications and communities (Xiang and Gretzel 2010; Weinberg 2009). Consequently, UGC “can be seen as the sum of all ways in which people make use of social media” (Kaplan and Haenlein 2010, p.61).

The term marketing on the other hand, is mainly concerned with the traditional promotional principles and techniques, encompassing "advertising, personal selling, public relations, publicity, direct marketing, and sales promotion” (Mangold and Faulds 2009, p.357). Marketing in an SM context enables marketers to make use of the Internet as a communication channel (Gordon 2012; Kollmann 2007). Therefore, SMM can be classified as an online marketing tool that enables “marketers to (efficiently and effectively) communicate a brand's benefits, value proposition, and personality to its target audience” (Tuten 2008, p.56; Akar and Topçu 2011).

This research uses the definition, provided by Kaplan and Haenlein, who claim that SMM can be characterised best as "Internet-based applications that build on the ideological and technological foundations of Web 2.0, and that allow the creation and exchange of User Generated Content” for marketing purposes (Kaplan and Haenlein 2010, p.61). 


\subsection{Social Media Marketing}

In terms of the benefits associated with SMM it represents an important strategic approach in online marketing. In particular, SMM focuses on the achievement of direct customer contact through SM-activities, as well as aims towards product or service promotion through various platforms (Hettler, 2010). According to Aral, Dellarocas and Godes (2013, p.3) "Social media are fundamentally changing the way we communicate, collaborate, consume and create”. This has resulted in benefits and opportunities that make social media integral to marketing strategy (Barnes, 2010). Marketers are seeking to capitalise on these opportunities for an increase in quality engagement and superior communication with customers, to deliver higher levels of customer acquisition and retention (Naylor. Lamberton \& West, 2012). In comparison to traditional marketing communication channels SM allow organisations to combine sales and promotion in new ways (Valos et al 2014).

An online study, conducted by two public German television broadcasters: ARD and ZDF, revealed that $73 \%$ of the whole German population actively uses the Internet as a source of information. Almost 58\% of these Internet users participate in media-sharing, e.g. YouTube.com, and already 39\% are registered in social networks like Facebook (ARD/ZDF, 2011a; ARD/ZDF, 2011b). Accordingly, SM-platforms can potentially offer organisations a variety of different channels to market products by directly communicating with a large target audience (Palmer \& Koenig-Lewis, 2009).

Based on a study conducted by the Social Media Examiner (2011), findings suggest that $88 \%$ of all marketers surveyed claimed to use SMM to increase the level of exposure of their organisations. Moreover, another $72 \%$ identified that increased traffic adds particular value to their marketing effort. Consequently, higher traffic can increase brand awareness, improve public reputation, as well as boost search rankings (Weinberg, 2009). Improved search rankings have been identified by the study as an autonomous benefit (62\% of all participants agreeing). In addition, qualified leads generated, and the reduction of overall marketing expenses, have 
been identified as equally important SMM-advantages (Borges, 2009; Weinberg, 2009). Comparably low (43\%), but also vital, are the number of marketers, who perceive increased sales of products and services as an advantage of SMM-activities.

In line with these findings, a study by the German Marketing Institute (DIM, 2011) that took into consideration the advantages of SMM-activities from a corporate perspective revealed similar results. Amongst all participating organisations, about $76 \%$ determined customer loyalty to be their main SMM objective. The importance of customer loyalty, plus the creation of longterm customer relationships, against the backdrop of saturated markets emphasises the significance of SMM in today’s business environment (Borges, 2009). In addition, increased brand awareness (70\%), improved product and/or brand reputation (58\%) as well as acquisition of new customers (53\%) have been determined as reasons for marketers to engage in SMM (DIM, 2011). These results align with findings provided by Key Note (2010), as increased brand awareness, higher customer engagement and improved brand reputation have been identified as superior SMM-goals.

However, in comparison to traditional advertising, SMM is suffering a lack of control as the Internet is literally a consumer-owned domain (Evans 2010; Hoffman and Fodor 2010; Tuten 2008; Vollmer and Precourt 2008). For instance, marketers "cannot control the content and frequency” of information disseminated by consumers any longer (Magold and Faulds 2008, p.359). To become and to remain successful, organisations have to accept that within the SMenvironment, consumer power is much stronger than their own. Consequently, companies need to reconsider their strategic approach to SMM-practices, showing willingness "to give up control of the message” as well as allowing consumers to provide criticism and constructive input (Kietzmann et al. 2011; Weinberg 2009, p.14). Moreover, marketers face the risk of choosing the wrong SM-applications. In order to operate effectively, organisations should select SM-platforms carefully, to avoid wasting resources and efforts (Kaplan and Haenlein 2010). Especially, in light of the sustainability of SMM-endeavours, not every new marketing trend is 
likely to be successful. Therefore, organisations are well-advised to focus only on a few platforms, and to spread marketing related content or other corporate information cautiously without being intrusive (Zunke 2012). Otherwise, enterprises may risk damaging their corporate public reputation, which is exemplified by a survey from Deloitte LLP (2009). The results revealed that $74 \%$ of all participants agreed on the fact that SM can cause damages on a product's, service’s, or brand's reputation (Deloitte 2009).

This is also demonstrated by an empirical study, conducted by TOUROM (2011), in which SMengagement of global airline organisations is identified. The study revealed that about $91 \%$ of all involved aviation enterprises have implemented a profile page on Facebook. In addition, another $87 \%$ operate a corporate Twitter- account, providing useful information to followers. Additionally, $100 \%$ of all included airlines are represented on YouTube, whereas about 50\% actually provide content via their own YouTube channel. Nevertheless, these findings also imply that SM is already a well established tool in contemporary marketing activities of airline companies. Yet, these findings also reveal that the degree of sophistication in regard to SMM-practices varies. This is exactly what Kim (2008, p.312) found out when claiming that "most companies recognize the value of social media advertising, (but) not have figured out how to execute these kinds of campaigns”.

The measurement of SMM-efforts is a crucial task to marketers in order to quantify and evaluate the success or otherwise of applied integrated marketing communications. The most difficult task organisations are facing internally is the ubiquitous "desire to quantify the return generated by investing in social media” (i.e. cost of sales, return on sales for SM-investment) (Hoffman \& Fodor 2010, p.42). However, SMM represents a complex phenomenon and success measures can often not be quantified; rather qualitative metrics, that take into account more interpersonal aspects, have to be considered (e.g. consumer motivations to use SM) (Fisher, 2009; Weinberg, 2009). Therefore, SMM-initiatives should not solely be measured in monetary units, but should also investigate consumer intentions to engage in SM-applications (Hoffman 
\& Fodor, 2010). To identify SMM's acceptance amongst consumers, measures like the frequency of website visits (i.e. traffic), number of comments or 'likes' in a social network, or the number of replies on media-sharing websites can provide information on an SMapplication's attractiveness.

\subsection{Content}

When SMM was in its infancy companies viewed success as simply as the number of users socially connected to the brand. To generate this volume firms aggressively acquired fans and followers on platforms like Facebook by investing heavily on adverts. With early audits suggesting that only about $1 \%$ of an average firm’s Facebook fans show any engagement with the brand by Liking, sharing or commenting, attention shifted from acquisition of followers to the design of content that achieves better reach and engagement amongst social media followers (Lee, Hosanagar \& Nair, 2014). SM rapidly moved from simply being a channel in the communication strategy of a company to become a "game changer" providing engagement with customers (Bernabe-Moreno et al, 2015).

Digital marketing is segmented into three categories: paid content (for example pay-per-click advertisements), owned content (social media pages and company web site) and earned content (user reviews and media coverage). Earned content is seen as the most elusive, and a vital aspect of how an organisations image is perceived (Bagley \& Lanz, 2014). Martin and Todorov (2010) suggests the challenge for brand marketers in the airline industry, in line with other commercial organisations, is to develop social media based engagement opportunities that keep customers connected throughout the day. This pushes owned content out to customers, who in turn engage in the earned content so eagerly sought. However, developing branded social content that accomplishes these objectives can be difficult (Ashley \& Tuten, 2015), who found in their study that while social media participants seek entertainment and informativeness, entertainment is a stronger motivator of engagement. Developing content that is informative but 
above all entertaining will be returned to in the final section, as this seems an area that the industry can be creative with.

In the era of social media, customers have become active content creators through expressing and sharing their opinions, thoughts, and perceptions of brands and businesses through online reviews, blogs, Tweets and Facebook posts, collectively referred to as "user-generated content" UGC (Nam \& Kannan, 2014). The prize of engaging customers to the extent that they are providing (UGC) needs to be recognised. The challenge for marketers is to provide relevant and engaging content for customers. Without entertainment and informativeness, SMM performance will not be optimised through owned and earned content. Getting the right content then is the key to successful SMM, which leads on to the aspect of customer resistance to SMM.

In order for airlines and brands generally to capitalise on SMM investments, knowledge of how consumers interact with, and respond to, the medium is necessary. Hargittai \& Hsieh, 2011, cautioned against treating all users of social media networks as a homogeneous group, finding that SMM is more effective for some segments than others. Follow on research by Campbell et al 2014, identified and profiled a large segment of consumers (38\% designated “Actives” and “Talkers”) who can be influenced by marketing on a social network application, largely through this groups desire for information. However, in this 2014 study there were only 9\% designated “Averse” and were found not to be influenced by SMM.

The review of literature has revealed that SMM is a new marketing phenomenon that has augmented, but not replaced traditional marketing practices. SMM primarily makes use of various online SM-platforms to provide content to consumers or other institutions. Generally, this is achieved through a two-way direct communication approach. This new marketing paradigm has evoked from eWOM and also resulted in viral marketing, which is used to spread a message like an epidemic across the Internet. For this reason, SMM allows dissemination of information virtually disempowering marketers to have control over the message. Further, such content is published on multiple platforms, encompassing blogs and microblogs, social 
networking websites, media-sharing websites, social news and bookmarking websites as well as forums and bulletin boards.

\section{Methodology}

The research approach can either be deductive or inductive. Deductive research depicts the most common theory and is built upon "the basis of what is known about a particular domain and of theoretical considerations in relation to that domain” (Bryman and Bell 2007, p.11). Based on this theory, a hypothesis is consulted and empirically examined, according to its validity (Wilson 2010). In contrast to this, an inductive research approach mainly attempts to achieve the creation of a new theory as an outcome. Thus, inductive research "involves drawing generalizable inferences out of observations”, to gather relevant empirical data (Bryman and Bell 2007, p.14). 
The chosen approach for this research was primarily inductive, as it is intended to achieve new insights through the collection of empirical data on consumer attitudes towards German airline organisations' SMM-practices. Nevertheless, deductive elements (i.e. SMM-theory, German airline organisations' current SMM-efforts) were also used, as the existing body of theory and knowledge was consulted as a basis for the empirical investigation. According to Saunders, Lewis and Thornhill (2007, p.119), such a mixed approach is "perfectly possible" and can be more advantageous to the research project's outcome than the strict separation of the approaches.

\subsection{Qualitative vs. Quantitative}

Qualitative research embodies an amalgamation "of the rational, explorative and intuitive (...) analysis of data” (Ghauri and Grønhaug 2005, p.110). Therefore, qualitative research gears towards the analysis of meanings rather than frequencies (Saunders, Lewis and Thornhill 2007). This aspect is of particular importance, as this technique "allow(s) the researcher to provide elaborate interpretations of market phenomena without depending on numerical measurement” (Zikmund and Babin 2007, p.129). In this regard, qualitative research refers to more social and behavioural sciences, aiming towards critically "analysing situations, recognizing and avoiding biases (as well as) obtaining valid and reliable information” (e.g. through an interactive interview) (Ghauri and Grønhaug 2005, p.110). However, qualitative research commonly has a subjective character. Therefore, opportunities for systematic comparisons and generalisation of findings are limited (Saunders, Lewis and Thornhill 2007).

Quantitative research is concerned with empirical research that systematically identifies, analyses and utilises numerical data (Zikmund and Babin 2007). Such findings commonly derive from large-scale examinations, aiming towards a categorised description or a ranked order (e.g. 
graphs, charts). From a marketing point of view, quantitative research is of highly expressive value since it is statistically reliable and comparably easy to appraise (Saunders, Lewis and Thornhill 2007). Moreover, quantitative research is valuable as it examines how a large and representative group of individuals is affected by a certain phenomenon (Ghauri and Grønhaug 2005). Therefore, the most common methods to quantify empirical data through a survey strategy are represented in conducting questionnaires (Zikmund and Babin 2007). Yet, a possible drawback may occur if data, which might not appear to be quantitative, is neglected despite its relevance (Saunders, Lewis and Thornhill 2007). Based on the objectives of this research the quantitative approach was considered the most suitable.

\subsection{Primary data collection method}

Due to the fact that primary data is defined as "data collection at source", it was decided that the use of Internet-mediated or online- questionnaires is most suitable for the purpose of this study (Collis and Hussey 2003, p.160). This choice was supported by the fact that questionnaires are considered to be the most effective and appropriate quantitative research method for conducting primary research in light of a survey strategy (Bryman and Bell 2007; McGivern 2009). However, various types of questionnaires exist and different collection methods can be used. Typically, online questionnaires represent a widespread and effective mode to collect data with comparably reasonable effort, time and cost, where participants get actively involved through self-completion. Furthermore, the use of Internet-mediated questionnaires enables the research to acquire and develop inductive insights, by quantitatively obtaining consumers' perceptions towards German airline organisations' SM-practices (Bryman and Bell 2007; Denscombe 2007). Questionnaires "entail several questions that have structured response categories (whereas) some open-ended questions may also be included” (Marshall and Rossman 
2006, p.125). In addition, questionnaires are usually pre-coded, so that completion is relatively easy for respondents. Data collection and analysis is also simplified for the researcher (Bryman and Bell 2007; Sue and Ritter 2011). Such an approach guarantees more consistent and genuine data, as participants may not be influenced by interpersonal factors as in a face-to-face interview situation (Aaker, Kumar and Day 2009; Bryman and Bell 2007). Moreover, data can be processed conveniently by the use of online survey tools (Sue and Ritter 2011).

However, conducting online questionnaires also has some weaknesses. A critical drawback to such an approach is the required Internet accessibility for the researcher as well as for respondents (Fink 2006). Fixed questions may also cause biases, as participants are forced to provide an answer even if they have no knowledge about a particular topic. Lastly, questionnaires may not be answered honestly, because it might be possible that respondents do not answer conscientiously to questions (Denscombe 2007; Sue and Ritter 2011). Nevertheless, for the purpose of this study it was decided to conduct a self-administered questionnaire using the Internet as a delivery and collection channel. Online research presents an appropriate data gathering method that produces, in comparison to postal, face-to-face or telephone surveys, similar response rates and "might actually be preferred (by participants) where either is an option” (Denscombe 2007, p.24). The use of online surveys is considered preferable to alternative method.

Due to the fact, that this research was concerned with online marketing tools, the questionnaire's target group consists of Internet users. Hence, the drawback of required Internet accessibility diminishes. Self-completion questionnaires represent one of the most effective tools to collect data for the purposes of this research and allows for the quantifying and measuring of structural relationships between consumers' perceived attitudes in context of German airline corporations' 
SMM-efforts (McGivern 2009). It was decided to use the online service provider NETQ to design and conduct the questionnaire. This online survey tool provides a multitude of options to design, conduct and analyse this study's survey.

\subsection{Sampling}

Sampling "is almost invariably encountered in quantitative research" as it is of particular importance to this study (Bryman and Bell 2007, p.180). The sampling technique enables the researcher to define a target audience (e.g. individuals or objects), where information can be gathered, analysed and interpreted for census purposes (Saunders, Lewis and Thornhill 2007). As suggested by Denscombe (2007, p.13), "researchers are frequently faced with the fact that they cannot collect data from everyone who is in the category being researched". Thus, a sample represents a sub-set of the entire population that is relevant to this study, as the accessibility of all available data is limited due to time and money constraints (Sekaran and Bougie 2010; Saunders, Lewis and Thornhill 2007). McGivern (2009) suggests it is essential to define the target population, identify an appropriate sampling technique as well as select the sample size, prior to conducting a questionnaire.

\subsection{Selection of the target population}

The target population defines an entire group of people, events or things that share a common set of characteristics on which an investigation's outcome can be based (Sekaran and Bougie 2010). This research focuses on the identification of consumer perceptions of German aviation enterprises' SM-activities on various online platforms. Therefore, the target sample consists of German consumers, who have Internet access via computer or smart-phone devices as well as 
use SM-applications. Further, there will be no distinction made in regard to gender, age, ethnical background, occupation, disability or social status.

\subsection{Selection of sampling technique}

According to Denscombe (2007), Sekaran and Bougie (2010) and Wilson (2010) two different types of selecting the research sample exist, i.e. probability sampling and non- probability sampling. Probability sampling, often also referred to as representative sampling, allows “every item (e.g. people or events) in the population” an equal chance to be included in the sample (Wilson 2010, p.194; Denscombe 2007). This type of sampling is mostly related to survey-based studies where inferences about the sample of particular populations need to be made (Saunders, Lewis and Thornhill 2007). However, the implementation of probability sampling is comparably time-consuming and costly. Moreover, a complete sampling frame (i.e. individual units must be known and be accessible), which makes this sampling technique unfeasible for the purpose of this study (Bryman and Bell 2007; Wilson 2010).

In contrast, non-probability sampling implies that "the probability of each case being selected from (a) total population is not known” (Wilson 2010, p.198). Thus, this technique does not provide every individual in a population with an equal chance of being included in a sample. Therefore, this sampling method is used when representativeness of a sample is less important or impossible (i.e. no access to a comprehensive listing of each unit of the population). Nonprobability sampling does not allow statistical generalisation, but general assumptions can still be made (Denscombe 2007).

Due to the fact that the entire sample frame is unknown, non-probability sampling has been chosen as the most appropriate sampling technique. This technique is appropriate because this 
research is concerned with the identification of consumers' opinions towards SM. This research has chosen to determine the sample for this particular research through self- selection sampling. By adopting this particular technique all potential respondents can decide if they wish to take part in the research. This technique allows for the use of appropriate online media sources (Denscombe 2007; Saunders, Lewis and Thornhill 2007).

The questionnaire was distributed using the researcher's personal network (i.e. consisting of about 400 people) as well as through posting it on various SM-platforms (i.e. in the message board of the author's previous university, which is accessible to approximately 3000 individuals). This technique is also less costly and time-consuming than many other collection techniques Finally, in regard to analysing the German airline industry's SMM-practices, sampling was unnecessary, as the entire population, i.e. German airlines, represents a small number of units.

\subsection{Sample}

Based on the determination of self-selection sampling as the underlying method, it is essential to get as many participants involved as possible. As self-selection sampling is open to every informed person that would like to take part, a detailed indication of an intended response rate cannot be provided. However, to be able to achieve reliable data findings, a desirable response rate requires the participation of at least 100 respondents, as recommended by McGivern (2009). In addition, a sample of 100 participants reduces the standard error (i.e. typically estimated to be a $\pm 5 \%$ margin of error) and ensures to provide a representative result (Denscombe 2007).

A total of 132 functional surveys were returned for analysis. The sample consisted of a male/female mix of 53\%/47\% respectively. The majority of surveys fell within the $19-29$ age 
range (52\%). It was encouraging to see responses obtained from older age groups (20\% that were 50+), which increases the representativeness of this study as well as implies that the Internet is not only used by the younger population as a gathering source of information. In terms of income levels, 58 respondents (44\%) had an annual income of less than €20,000 supporting, to some extent, the youthful profile identified by the age demographics. However, with the remaining $56 \%$ of responses distributed over the other response categories (>€20,000 to $€ 70,000+$ ), this exemplifies the diversity and range of the population sampled despite the high proportion of respondents with a relatively low income.

\subsection{Survey design}

This research focused on a survey strategy to ensure the alignment of exploratory and descriptive practices, as well as to employ a deductive approach (McGivern 2009; Zikmund and Babin 2007). This approach allows for the collection of large amounts of data from a large sample size in a relatively short period of time (Bryman and Bell, 2007). A survey is also an "appropriate mode if inquiry for making inferences about a large group of people based on data drawn from a relatively small number of individuals in that group” (Marshall and Rossman 2006, p.125). The use of a survey methodology also enables more in-depth insights by placing customised questions (Zikmund and Babin 2007). In addition, data collected by a survey allows for teh use of SPSS as a method of quantitative analysis. The use of the survey method also assists in the collection data that could be representative for the whole German population (Gray 2009; Saunders, Lewis and Thornhill 2007, Zikmund and Babin 2007).

However, a possible drawback is that data may be "of little value for examining complex relationships or intricate patterns of interaction” (Marshall and Rossman 2006, p.126). Moreover, 
inaccuracies in collected data may exist and errors cannot be completely excluded (Saunders, Lewis and Thornhill 2007).

\subsection{Data analysis}

The questionnaire has been designed using closed questions only to ensure more simplicity when analysing and systematically identifying the questionnaire findings (Kent 2007). The online survey tool NETQ was used to design and conduct the survey, but also to derive descriptive statistics and figures. The data is pre-coded by the programme, which allows the user to export findings as a Microsoft Excel file for further analysis and adaptation of graphical illustrations.

\subsection{Limitations of the study}

The literature review is relatively limited due to the fact that SMM-practices within the German airline industry have received only limited coverage by scholars to date. Additionally, it has to be noted that this research is limited in that it focuses on a particular area within SMM (i.e. consumer perception and SM-efforts of German airline organisations). Therefore, a generalisation for the entire industry is inappropriate, but rather a fundamental understanding of the field of study can be achieved.

It is also acknowledged that this research may be biased as a result of the fact that the majority of participants are about thirty years or younger (i.e. survey disseminated through message board of the authors previous university). Also, the nature of an online questionnaire does not provide the opportunity to deeply probe and clarify participants’ responses to particular questions.

From an ethical stand point this research has taken into consideration all issues of confidentiality and plagiarism and all used data sources are correctly acknowledged in the reference list. Ethical 
considerations embody a critical aspect of this study and refer to the appropriateness of the research in terms of the rights of all participants (Saunders, Lewis and Thornhill, 2007). Consequently, participants are assured of anonymity and the surveys did not collect information on the exact geographic location of participants or their IP or email addresses.

\section{Discussion of Findings}

Overall, German airline organisations have clearly identified the need to offer their customers a wide array of different SM-platforms to connect with. In general, all major German airlines widely operate at least a Facebook profile page as well as offering updates on their corporate Twitter accounts. This user behaviour aligns to the empirical study conducted by TOUROM (2011), when identified that these two channels were most likely to be used by airline organisations and also support studies, conducted by Social Media Examiner (2011) and DMI (2011) discussed earlier.

A summary of the extent of Social Media Platform usage by German airline organisations can be found in Table 1. 


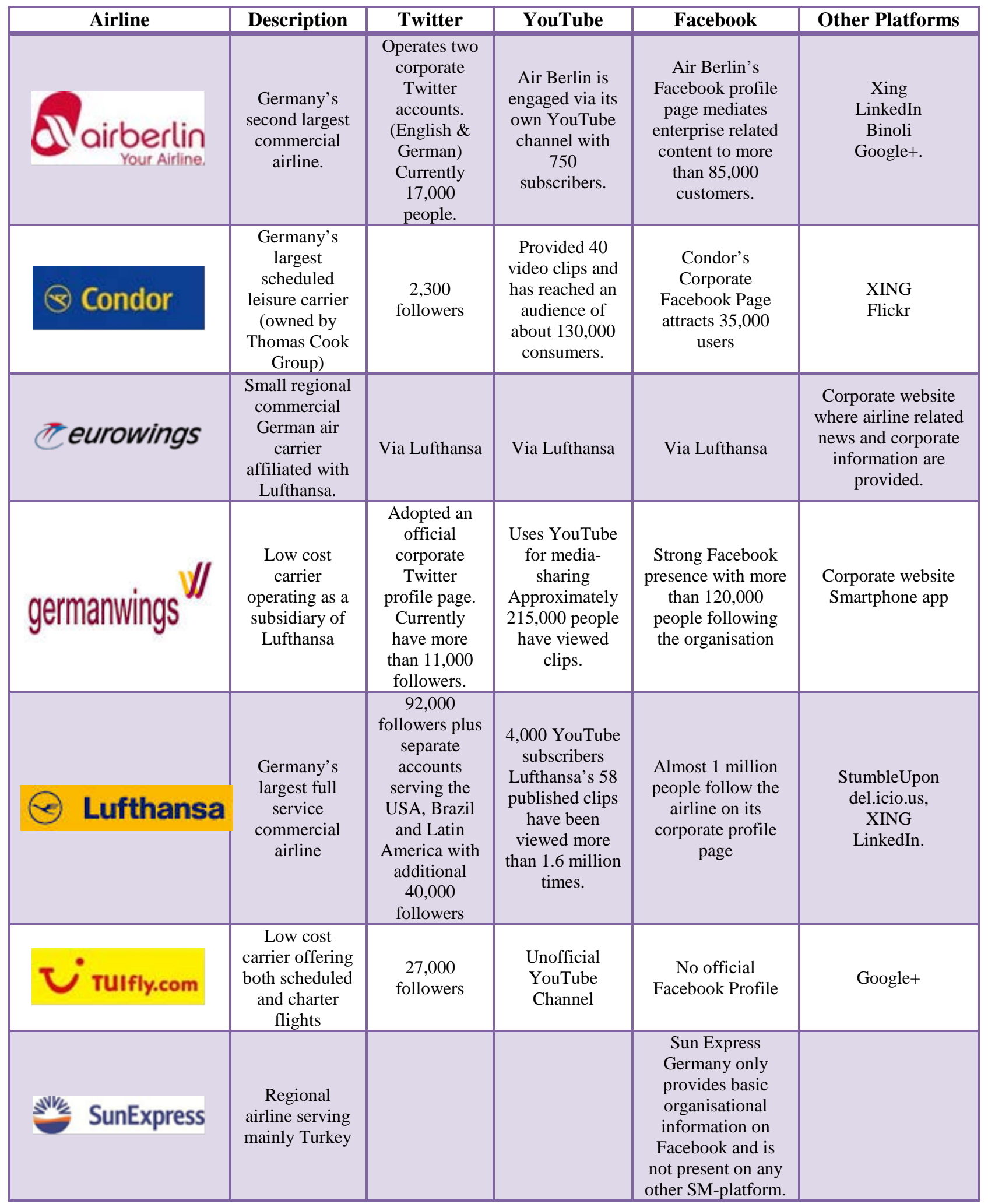




\subsection{Consumer perceptions towards Social Media}

Traditional marketing concepts still represent a powerful set of outreach tools that have not completely been replaced, but rather augmented by the new marketing paradigm, as predicted by Winer (2009). In particular, this is exemplified by a vast number of respondents who agreed to make use of TV and radio advertisements (68\%) or journal and magazine advertisements (50\%), to gather brand or product-related information (Figure 2). Nevertheless, new and digitalised communication concepts are becoming increasingly complex, useful and powerful to consumers. This can be illustrated by the fact that various SM-platforms have been utilised by respondents, to access information through the latest technological innovations and applications (i.e. blogs, social networks) (Kane et al., 2009; Li \& Bernoff, 2008).

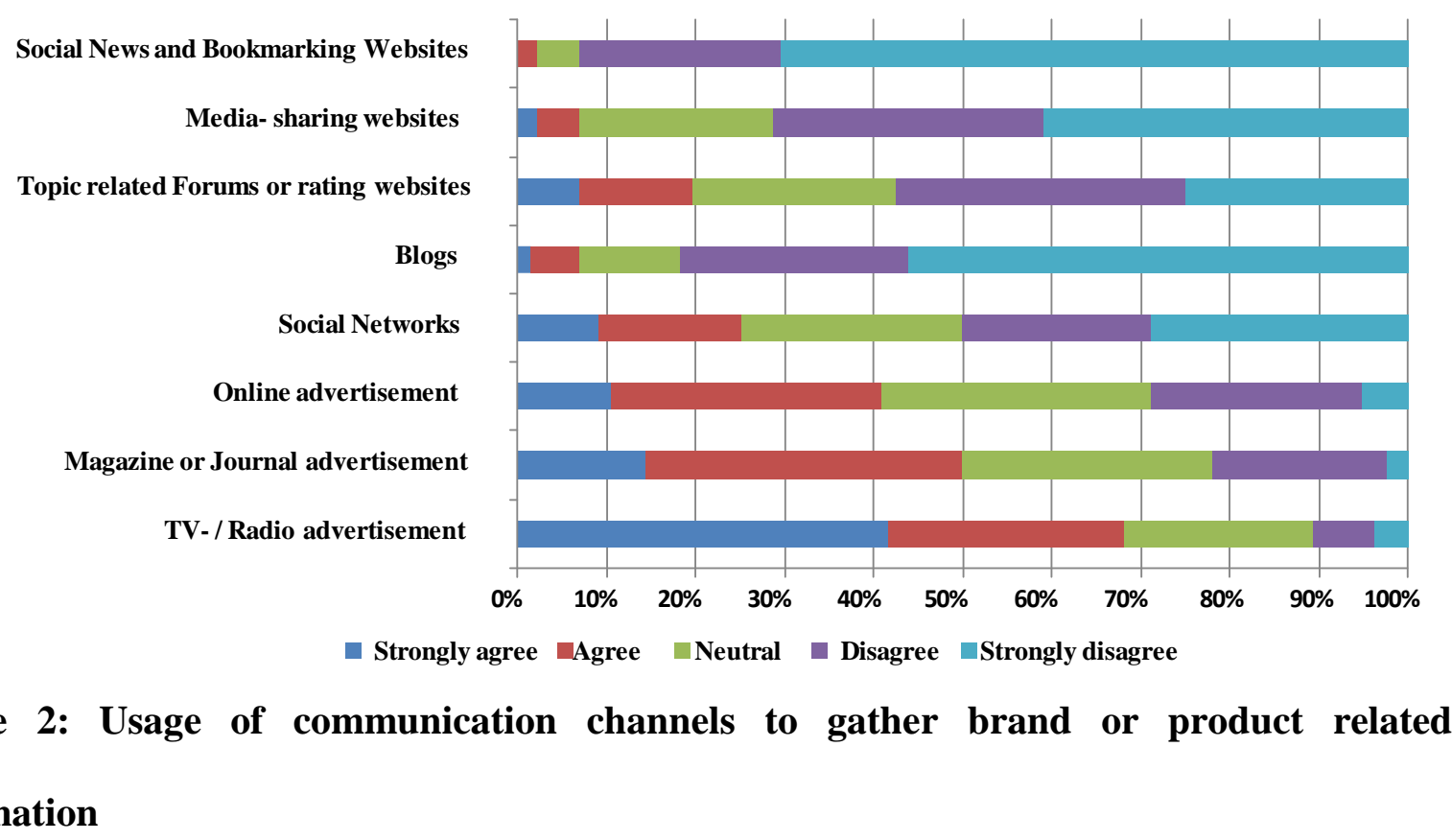

\section{information}

These findings align with German SM-user preferences on their frequency to log in on various

platforms. Noticeably, there is a strong dependency amongst online users on the most common 
platforms. Particularly Facebook attracts the vast majority of participants, resulting in almost $56 \%$ of all respondents logging in at least once a day (48\% several times per day), predominantly to keep in touch with friends or other persons or for their own amusement. YouTube represents another SM-platform that is utilised by $60 \%$ respondents a minimum of once a week. Surprisingly, almost $20 \%$ of all participants stated they use the social network Google+, as well as the social business network Xing, at least once a week. By contrast, all other SM-platforms are barely visited.

German online users have developed a distinctive affinity towards the social network Facebook, as only $22 \%$ admitted to not having used this application at all. This is also observable in the large number of respondents who follow German airlines through Facebook. Besides, a medium tendency towards the usage of media-sharing website YouTube can be identified, as at least 56\% visit the website weekly. These findings correlate with the study by ARD/ZDF (2011a; 2011b), which identified Facebook and YouTube as the most frequently used SM-channels by Germans. In addition, social network Google+ is used regularly by a small number of individuals. However, several other platforms like social news and bookmarking websites (i.e. Digg; del.icio.us; StumbleUpon) or blogs, such as Plurk, are rarely used by Germans. This indicates the diversity of user behaviour amongst different geographical locations, for instance StumbleUpon has recently recorded 20 million users, but the service remains almost unknown in Germany (StumbleUpon, 2012). Similarly, the unpopularity of microblogging website Twitter is significant, since the blog is almost ignored by respondents. Especially in relation to current SMactivities, employed by German airlines, these findings are contrary to what Zarella (2010) stated, when claiming that efforts in a Twitter engagement pay off quickly and result in great buzz. In light of the fact that almost every German airline organisation has implemented its own 
corporate Twitter account, it can be questioned whether this initiative is as successful as intended.

German SM-users also value various platforms to support them in regard to making purchasing decisions, gathering product or brand- related information as well as gaining knowledge and skills (Figure 3). However, 82\% of respondents were reluctant to share the contents with other users. Nor do they regularly post comments on an organisation's profile page (in total 80\% disagreeing). Again, these aspects coincide with the fact that German online users prefer to use SM as an option to keep up contact with others as opposed to any other use.

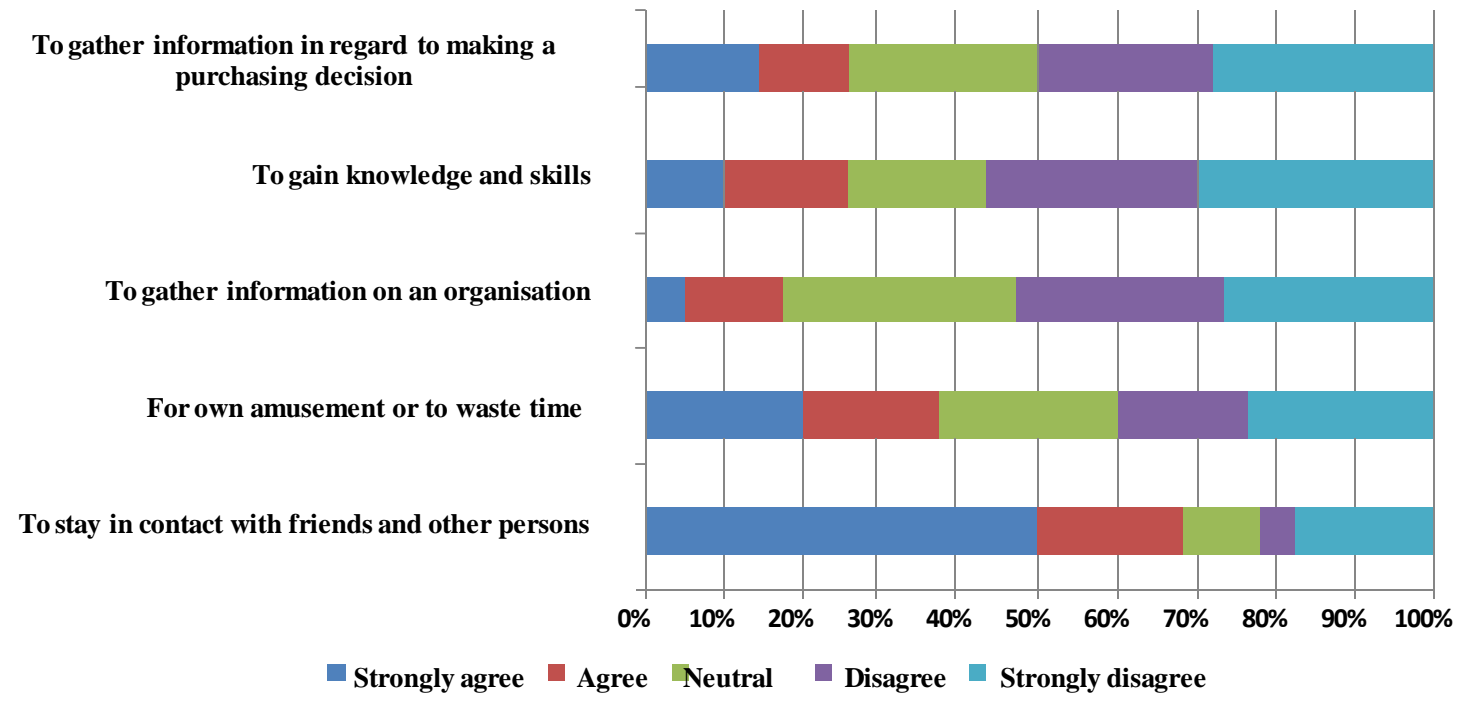

Figure 3: Purpose of respondents' using various social media platforms

Despite the high number of users who predominantly utilise SM-platforms in order to stay in contact with their friends or merely for amusement, there are also considerable activities in regard to seeking organisational or product related information. Hence, for German airline organisations this clearly implies the significance of having an active online presence. If organisations are accessible through multiple SM-platforms, the probability of being recognised by online users is increased. 
German online user behaviour appears to be more passive than active. This is of particular importance to airline organisations as they use this information to appropriately design published content. For instance, Condor's Twitter online game campaign acknowledges this issue. The airline has identified the need to attract online users without being intrusive (Kaplan \& Haenlein, 2010). Moreover, Germanwings’ viral campaign addresses this behaviour and aims towards the successful employment of eWOM through buzz-creation.

\subsection{German consumer's interactivity, involvement and perception towards airlines social media efforts}

The majority of German airlines are actively involved in SMM, by utilizing various channels to promote their brands and products. However, as argued by Zunke (2012), all commercial German air carriers clearly have focused on a limited number of platforms, encompassing the most popular channels like Facebook, YouTube and/or Twitter. In this research 67\% of the respondents claimed to be following at least one organisation through SM. Hence, the activities and efforts by the airline organisations can be perceived as valuable for marketing purposes. Moreover, there could be even greater potential due to the growing number of SM-users and thus

an increase in future followers. Especially, given that customers of organisations are likely to become fans or followers. This implies that these organisations have to please their existing customers by conveying a feeling of reward for their loyalty. As the results have shown, respondents value being given access to latest news, offers and promotions. 


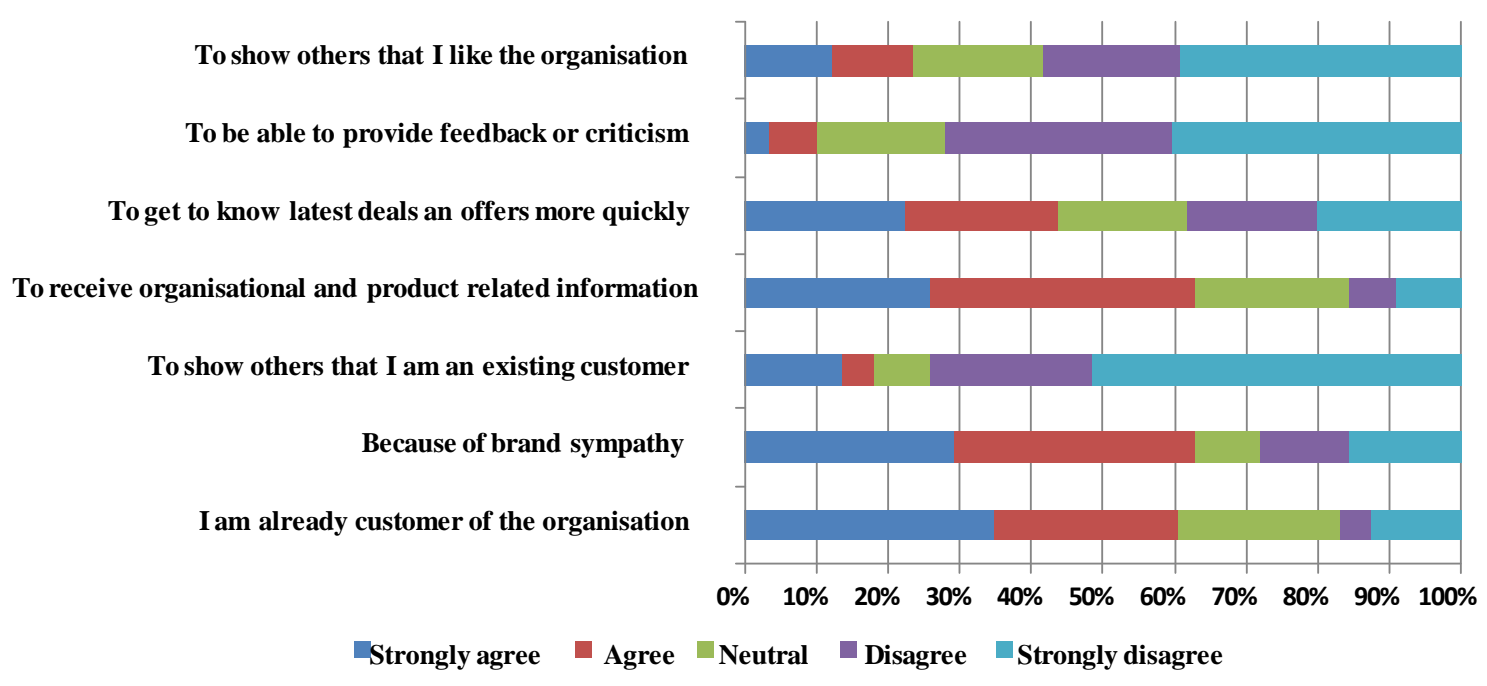

Figure 4: Reasons to become a fan or follower of an organisation, product or service

In terms of the reasons to become a follower $60 \%$ of respondents strongly agreed or agreed on:

- already being a customer

- having an affection for the organisation;

- receiving news on latest deals and offers more quickly.

Additionally, the vast majority named the supply of latest organisational and product related news as another reason to follow an organisation on a SM- platform. A considerable amount of respondents have become followers due to their affection for the brand or the organisation. In order to please these customers there should be a focus to provide content that gives reason for and even increases this affection (e.g. demonstrating social engagement). Beyond that, this also requires an organisation to interact with its consumer base appropriately and according to certain standards. This can be supported by the fact that respondents appreciate airlines that demonstrate 
a high degree of transparency by openly reacting to criticism (98\% of respondents) as well as communicating in an informal and personal manner (49\% of respondents).

The corporate website of an airline is frequently used by respondents to get access to latest news and promotional offers (figure 5). Airlines are encouraged to assure the constant flow of information in regard to news, offers and promotions, since a large number of respondents (68\%) limit their behaviour to reading posts and news.

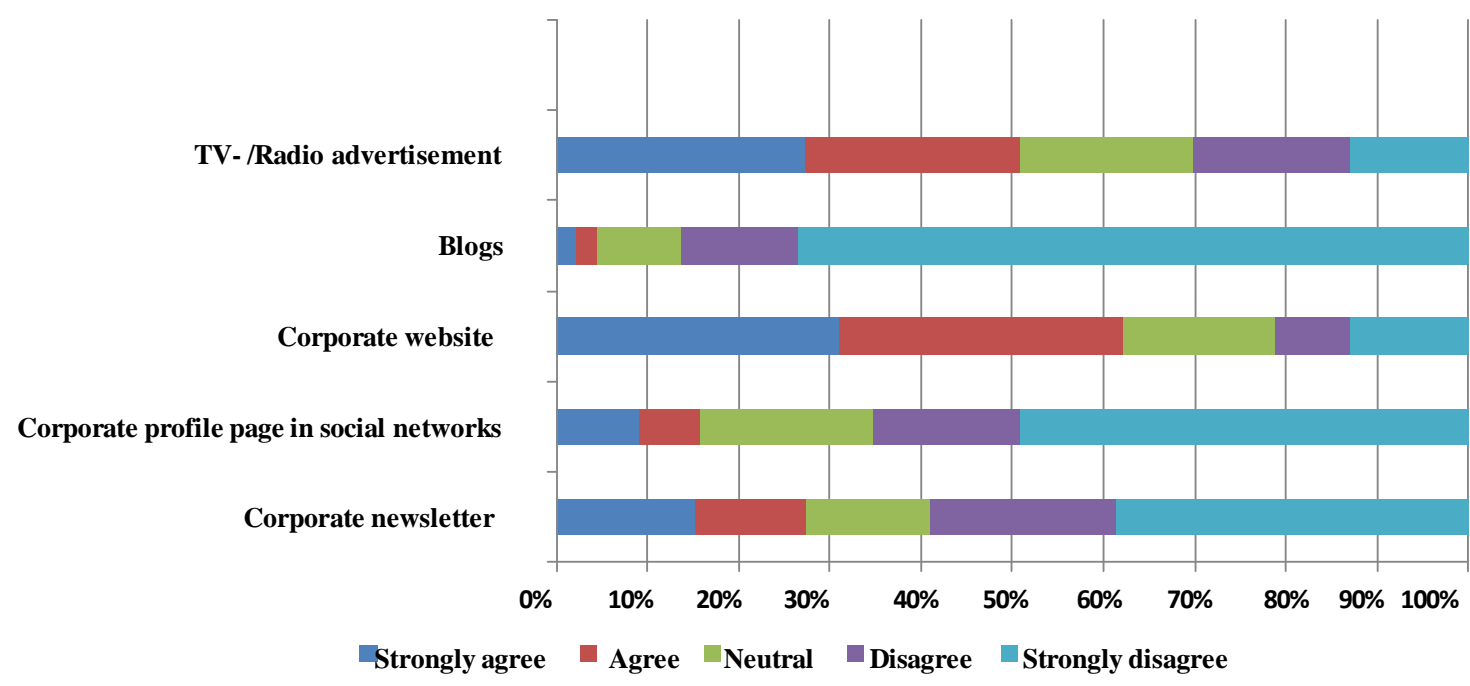

Figure 5: Respondents' perceptions of communication channels that are most likely to attract attention

The majority of respondents (65\%) suggested that it is necessary for airlines to provide multiple communication channels to consumers. These findings support the DIM (2011) report concerning SMM-objectives of enterprises. The aims of increasing customer loyalty, fostering long-term relationships, increasing brand awareness and reputation as well as acquiring new customers can therefore prove to be attainable with the help of existing SM-practices employed by these airlines. Even though only a small proportion of respondents are likely to recommend an 
organisation or product after having become a fan or follower (18\%), this number should not be regarded as definite. User activities, such as becoming a fan or follower or commenting on organisational content are visible to other users. Thus, despite not directly recommending a product or brand, users indirectly promote an organisation and consequently help to increase awareness.

It can also be identified that amongst the German society a certain potential for future growth of SM-services exists. Even though, the questionnaire revealed that the minority of respondents (26\% respondents) have some knowledge of SM-services of airlines, half of these (13\%) have already booked a flight due to an offer found on a SM-platform. It can be assumed that an increasing awareness of SM-services may result in an increasing number of bookings, triggered by SM-advertisements. This assumption is supported by the percentage of respondents, who consider that an attractive offer could motivate them to make a spontaneous journey (40\%). Therefore, airlines should increase awareness about their SM-efforts and activities.

However, it's clear the majority of respondents (64\%) tend to use traditional communication channels (i.e. TV and radio advertisements) or corporate websites, to get to know the latest news and offers. Consequently, airlines are well advised to use these 'traditional' media to increase their overall recognition of SM. It is essential to provide information on various channels (64\% of respondents). In this research figure 6 shows that at least $70 \%$ of respondents are not involved in any SM-activities of German airline organisations. In view of the fact that the respondents predominantly belong to the age group $19-29$ and that $66 \%$ of all participants use Facebook at least once a day, this figure is remarkably low and indicates potential for growth. 


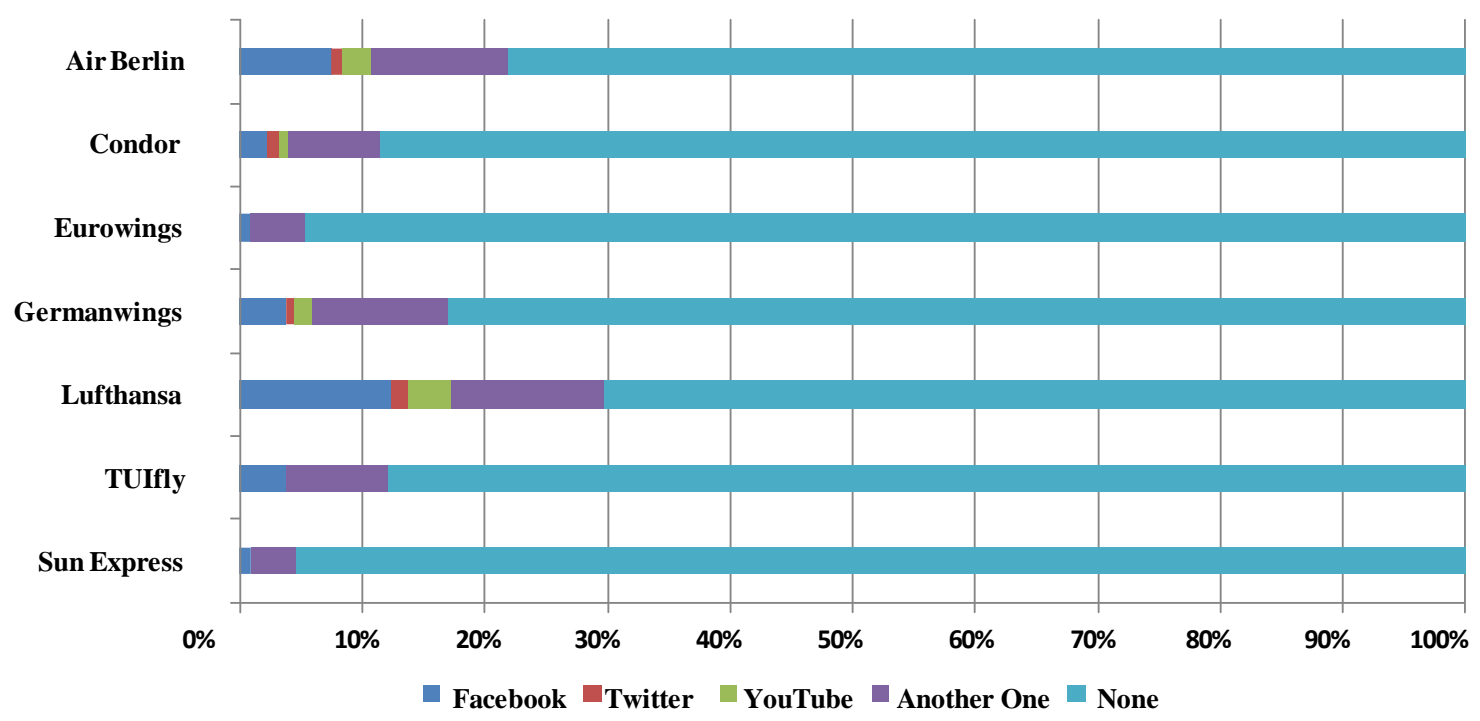

Figure 6: Responses to the question: Which German airlines' SM-activities do you follow on various platforms?

Surprisingly, almost none of the respondents are actively observing airline activities on Twitter and only a small number engage in following Air Berlin, Condor, Germanwings and Lufthansa on their corporate YouTube channels. However, these channels are not utilised as much as expected, since a vast number of respondents claimed to be following German airline organisations through another SM-platform. Lufthansa is followed by almost $30 \%$ of respondents on various platforms, Air Berlin by $22 \%$ and Germanwings with 18\%. As expected, Eurowings and Sun Express Germany are not followed by respondents as their SM-efforts are limited.

Nevertheless, the findings also revealed that German online users think that an airline is more reputable (29\%) and likeable (39\%) if it exhibits a high online presence. So far, this issue has 
been targeted successfully by the majority of airlines, since most are accessible through multiple SM-platforms. Many people already utilise different platforms and frequently receive corporate information through these channels. Although Facebook still represents the preferred platform amongst the respondents, this does not imply that airline organisations should concentrate solely on this channel. Their activities on less popular platforms such as Twitter are likely to be advantageous in the future, as suggested by the study conducted by TOUROM (2011). In fact, German airlines appear to be ahead of the current trend by getting familiar with platforms such as Twitter.

Several airlines (e.g. Air Berlin, Condor, Germanwings) have already identified the need for further technological improvements as well as to simplify the flight search and booking process. These initiatives include embedding a search and booking function directly on a SM-platform and offering adjusted applications that enable consumers to conveniently check flights via their mobile phone. The large number of respondents (88\%), who value reminders, provided by airlines about flights, their current status and possible delays provide opportunities for developments in this area.

\section{Conclusions}

As SMM is becoming increasingly important, organisations are constantly confronted with a variety of possibilities to promote and advertise their brands, products and services. Consequently, customers are also permanently offered new and innovative communication channels to gather, communicate, collaborate and share content.

Therefore, a review of existing literature has revealed that SMM is particularly important to marketers as it represents an effective marketing tool that is considered to be highly economic 
and guarantees fast and cheap dissemination of content. Hence, SMM has virtually revolutionised business-to-consumer communication enabling organisations to communicate brand benefits through various SM-platforms directly as well as indirectly to its existing and potential customers. Consequently, SMM represents an interactive two-way direct communication approach, which is based on a 1:n relationship, allowing the constant exchange of content in a circulated manner. Through this development consumers not only receive information, but also provide helpful insights to others, i.e. eWOM communication. In addition, viral messages provide marketers with another powerful SMM-tool. Such messages are often characterised by their controversial, sarcastic and epidemic character and are actively released and controlled by organisations before they spread across various platforms. In both cases, individuals act like consumers and producers at the same time (i.e prosumers) and actively promote an organisation through the dissemination of corporate content. This relatively new marketing phenomena has changed the way organisations and consumers interact and as a consequence enterprises need to be aware of a higher degree of consumer power in an online environment.

Due to the fact that the Internet has become a predominantly consumer-owned domain, organisations have to be willing to give up control of the message and try to operate with a high level of transparency without any obvious intrusions. The main focus of marketing initiatives should be narrowed down to only a few platforms to be able to precisely and efficiently target customers. It is crucial that organisations ensure the constant delivery of valuable news and information to customers.

The majority of German airline organisations have managed to utilise multiple SM-platforms as an effective communication tool. The only exceptions are Eurowings and Sun Express Germany. 
All other commercial air carriers (i.e. Air Berlin, Condor, Germanwings, Lufthansa, TUIfly) are actively engaging in only a few SM- activities, predominantly being active on Facebook, Twitter and YouTube. Using blogs and social networks, airlines provide regularly updated information on latest news, offers and deals to their customers as well as to serve assistance if any kind of queries occur. In this regard, it can be noted that all airlines openly and immediately reply to any kind of criticism, mostly interacting in an informal and personal manner. The only exception is Lufthansa, who answers any posts more formally, but also very politely. German airlines also offer their followers interactive games or lotteries to win flight tickets and to create a higher level of consumer interaction with individual brands. Besides that, some airlines, like Lufthansa and Air Berlin, also upload short video clips on YouTube, enabling followers to watch background information or documentaries on the company. Some airlines have also utilised other platforms to disseminate corporate content. Air Berlin, Condor and Lufthansa, for instance, all have a corporate profile page in the social business network XING, providing news to business travellers. Air Berlin and Lufthansa are both engaging in platforms that might not be well known by German consumers right now, but bear a certain potential for future growth (e.g. StumbleUpon, del.icio.us). All airlines also enable customers to receive a newsletter with latest information of news and offers. Additionally, the majority have created a mobile phone application, or at least adjusted mobile phone applicable corporate websites to allow smartphone users to conveniently search and book flights or to check-in online.

In addition to these findings, the questionnaire asked participants for their general SMengagement, their motivation and involvement in SM as well perception towards practices by German airlines. These results have revealed that most Germans make use of the Internet as an information source, but also still utilise traditional advertising modes (e.g. TV or 
magazines) to get to know brand or product related news and offers. Germans tend to have a strong affinity towards the social networking websites Facebook, XING, Google+ and the mediasharing website YouTube. Other platforms like social news and bookmarking websites or blogs (i.e. StumbleUpon or Twitter) have barely been used. The findings also revealed that even if respondents' roles are more passive, a lot of participants admitted to following organisations through SM to have access to news, information, offers and latest deals of brands and products. Besides that, German online users appreciate being given a platform to clarify queries as well as to publicly provide criticism or feedback. These results are also in line with participants' overall perceptions towards SM-practices employed by German airlines. Although respondents’ current knowledge of airlines SM-initiatives is limited and a vast number are still using traditional media, a certain growth potential can be identified as many participants are following Lufthansa, Air Berlin and Germanwings through SM. The reasons for this behaviour are diverse and range from the Germans' intent to be able to access news and information, (i.e. flight scheduling) through multiple channels, to the desire to be treated in an informal and personal manner within SM-platforms. Furthermore, it is important to respondents to be able to be given the opportunity to publicly express positive and negative experiences with an airline. Finally, respondents are not following German airlines on SM-platforms for image reasons. Rather they seek benefits in terms of latest offers, specials deals and promotions.

\section{Recommendations}

This paper has identified that there is widespread utilisation of SM amongst German consumers. Even though it seems as if traditional media are still Germans' primary information source, there is a continuously growing audience that makes use of SM-practices to gather brand and productrelated information. German customers predominantly tend to make use of SM to receive 
benefits in form of offers, deals and promotions so airlines should primarily focus on the fulfilment of these demands. It is suggested that German airlines should maintain their SMMefforts and intensify their initiatives.

Due to the fact that German consumers still gather a lot of their information from TV, radio, journals and magazine advertisements, it is suggested that airlines should continue to use traditional platforms to promote their existing SM-initiatives. Because of German consumers' strong affinity towards the social network Facebook, airlines need to put a higher emphasis on the acquisition of new customers on this platform. In particular, users who engage with an airline on Facebook should be encouraged with network specific promotions that are exclusively accessible to them. This approach might also generate lead to an increase in terms of new airline fans.

Beyond that, German airline organisations should continue to focus their SM-engagement on a manageable number of platforms in order to be effective and it is important for them to identify early, platforms that might become popular in the future. Furthermore, in light of German online users more passive role, airlines should try to implement more campaigns that do not rely on interaction. Viral campaigns, as seen on Germanwings' controversial video clip, are more likely to be successful, as consumers are able to passively observe these marketing efforts rather than being proactively involved in a campaign.

Finally, airlines should set a focus on integrating more applications to simplify processes and to enhance convenience for customers. These applications could entail smartphone applications for flight reminders or bookings. Especially on the backdrop of increasing numbers of smartphone users, these applications could be factors of success in the long-term. Consequently, these results 
represent the basis for further research in order to gain a more in depth understanding of this particular field.

\section{References}

Akar, E. and Topcu, B., 2011. An Examination of the Factors Influencing Consumers’ Attitudes Toward Social Media Marketing. Journal of Internet Commerce. 10(1), pp.35-67.

Aral, S., Dellarocas, C., \& Geddes, D. (2013) Introduction to the special issue - Social Media and business transformations: A framework for research. Information Systems Research, 24 (1), 3-13.

ARD/ZDF, 2011a. ARD/ZDF- Onlinestudie 2011 - Entwicklung Onlinenutzung. [online]. Munich/Mainz: ARD/ZDF Medienkommission. Online Survey 2011 - developing online use. [online]. Munich / Mainz: ARD / ZDF Media Commission Retrieved from: http://www.ard-zdfonlinestudie.de/index.php

ARD/ZDF, 2011b. ARD/ZDF- Onlinestudie 2011 - Nutzung. [online]. Munich/Mainz: ARD/ZDF Medienkommission. Online Survey 2011 - use. [online]. Munich / Mainz: ARD / ZDF Media Commission Retrieved from: http://ard-zdfonlinestudie.de/index.php?id=307

Ashley, C., \& Tuten, T. (2015) creative Strategies in Social Media Marketing: An Exploratory Study of Branded Social Content and Consumer Engagement. Psychology and Marketing, Vol.32 (1): 15-27 (January 2015)

Bagley, E., \& Lanz, L. (2014) The digital direction: content management and the marketing communications of today. HVS Global Hospitality Report, 24 February, pp.1-6 
Barnes, N.G. (2010). Tweeting and Blogging to the top. Marketing Research, 22(1), 8-13.

Bernabe-Moreno, J., Tejeda-Lorente. A., Porcel, C., Fujita, H., \& Herrera-Viedma, E. (2015)

CARESOME: A system to enrich marketing customers acquisition and retention campaigns using social media information, Knowledge-Based

Systems.http://dx/doi.org/10.1016/j.knosys.2014.12.033

BDL, 2012. Neue Studie belegt Schlüsselrolle der Luftfahrt für deutsche Volkswirtschaft. New study confirms key role of aeronautics for German economy. [online] Berlin: Bundesverband der Bryman, A. and Bell, E., 2007. Business Research Methods. 2nd ed. NewYork, NY: Oxford University Press Inc.

Colli, J. and Hussey, R., 2003. Business Research - A Practical Guide for Undergraduate \& Postgraduate Students. 2nd ed. New York, NY: Pelgrave Macmillian.

Deutschen Luftverkehrswirtschafte.V. Retrieved from: http://www.bdl.aero/de/pressepublikationen/pressemitteilungen/2012/33/

BMWI, 2009. Bericht des Koordinators für die Deutsche Luft- und Raumfahrt. [online]. Berlin: Bundesministerium für Wirtschaft und Technologie. Report of the Coordinator of German Aerospace Policy. [online]. Berlin: Federal Ministry of Economics and Technology. Retrieved from: http://www.bmwi.de/BMWi/Redaktion/PDF/B/bericht-koordinator-luft$\underline{\text { raumfahrt,property=pdf,bereich=bmwi,sprache=de,rwb=true.pdf }}$

Campbell, C., Ferraro, C. \& Sands, S. (2014) Segmenting consumer reactions to social network marketing. European Journal of Marketing. Vol.48 Issue 3/4, 432-452. 
Constantinides, E. and Fountain, S.J., 2008. Web 2.0: Conceptual foundations and marketing issues. Journal of Direct, Data and Digital Marketing Practice. 9(3), pp.231-244.

Chaney, P. (2009). The digital handshake - Seven proven strategies to grow your business using social media. Hoboken, NJ: John Wiley \& Sons Inc.

Constantinides, E., \& Fountain, S.J. (2008). Web 2.0: Conceptual foundations and marketing issues. Journal of Direct, Data and Digital Marketing Practice. 9(3), 231-244.

Deloitte, 2009. Social networking and reputational risk in the workplace - Deloitte LLP 2009

Ethics \& Workplace Survey results. [online]. New York, NY: Deloitte Touche Tohmatsu Limited. Available from: http://www.deloitte.com/assets/DcomUnitedStates/Local\%20Assets/Documents/us_2009_ethics_workplace

_survey_220509.pdf [Accessed 18 March 2012].

Denscombe, M. (2007). The Good Research Guide - for small-scale social research projects. 3rd ed. Berkshire: McGraw- Hill Education.

DIM, 2011. Social Media Marketing (SMM) in Unternehmen [online]. Cologne: DIM Deutsches Institut für Marketing GmbH - German Marketing Institute GmbH. Retrieved from: http://www.marketinginstitut.biz/media/studie_social_media_marketing_in_unternehmen.pdf

Euromonitor International, 2011. Transportation in Germany. [online]. London:

Euromonitor International Ltd. Retrieved from: http://www.euromonitor.com/travel-and-tourism$\underline{\text { in-germany/report }}$

Evans, L., 2010. Social Media Marketing: Strategies for Engaging in Facebook, Twitter \& other Social Media. Indianapolis, IN: Que Publishing. 
Fink, A., 2006. How to conduct surveys - A Step-by-Step Guide. 3rd ed. Thousand Oaks, CA: SAGE Publications Inc.

Fisher, T. (2009). ROI in social media: A look at the arguments. Journal of Database Marketing \& Customer Strategy Management. 16(3), 189-195.

Ghauri, P.and Gronnhaug, K., 2005. Research methods in business studies - A practical guide. 3rd ed. Harlow: Pearson Education Limited.

Gray, D.E., 2009. Doing Research in the Real World .2nd ed. London: SAGE Publications Ltd.

Gubish, M., 2014. Analysis: German airline market shifts to low-cost travel. [online]. London: Flight Global. Available from:

http://www.flightglobal.com/news/articles/analysis-german-airline-market-shifts-to-low-costtravel-402963/ [Accesses 4 March 2015].

Hanna, R., Rohm, A. \& Crittenden, V.L. (2011). We're all connected: the power of the social media ecosystem. Business Horizons. Vol.54 No.3, 265-273.

Hargittai, E. \& Hsieh, Y.P. (2010) Predictors and consequences of differentiated social network site uses. Information, Communication, and Society, Vol. 13 No. 4, 515-536.

Harris, L., \& Rae, A. (2009) Social networks: the future of marketing for small business. Journal of Business Strategy. 30 (5), 24-31.

Hettler, U. (2010). Social Media Marketing: Marketing mit Blogs, Sozialen Netzwerken und weiteren Anwendungen des Web 2.0. Marketing with Blogs, social networks and other applications of the Web 2.0. Munich: Oldenbourg Wissenschaftsverlag GmbH. 
Hill, R. P., \& Moran, N. (2011). Social Marketing meets interactive media. International Journal of Advertising. 30(5), 815-838.

Hoffman, D.L., \& Fodor, M. (2010). Can you measure the ROI of your Social Media Marketing? MIT Sloan Management Review. 52(1), 41-49.

Kane, G.C., Fichman, R.G., Gallaugher, J., \& Glaser, J. (2009). Community Relations 2.0: With the Rise of Real-Time Social Media, the Rules about Community Outreach Have Changed. Harvard Business Review. 87(11), 45-50.

Kim, S.J., 2008. Viewpoint - A Framework for advertising in the Digital Age. Journal of Advertising Research. 48(3), pp.310-312.

Kietzmann, J.H. et al., 2011. Social Media? Get serious! Understanding the functional building blocks of social media. Business Horizons. 54(3), pp.241-251.

Kollmann, T., 2007. Online-Marketing - Grundlagen der Absatzpolitik in der Net Economy. Basics of Sales Policy in the Net Economy Stuttgart: W. Kohlhammer GmbH.

Lee, D., Hosanagar, K., \& Nair, H.S. (2014) The Effect of Social Media Marketing Content and Consumer Engagement from Facebook.

Lee, D., Hosanager, K. and Nair, H., 2014.The effect of social media marketing content on consumer engagement: evidence from Facebook. [online]. Philadelphia: The Warton School, University of Pennsylvania. Available from:

http://papers.ssrn.com/sol3/papers.cfm?abstract_id=2290802 [Accessed 3 March 2015] 
Li, Y.-M., Lin, C.-H., \& Lai, C.-H., (2010). Identifying influential reviewers for word-of-mouth marketing. Electronic Commerce Research and Applications. 9(4), 294-304.

Mangold, W.G., \& Faulds, D. J. (2009). Social media: The new hybrid element of the promotion mix. Business Horizons. 52(4), 357-365.

Marshall, C. and Rossman, G.B., 2006. Designing Qualitative Research. Thousand Oaks, CA: SAGE Publications Inc.

McGivern, Y. (2009). The Practice of Market Research. 3rd ed. Harlow: Pearson Education Limited.

Marketline, 2014. Airlines in Germany: May 2014. London:MarketLine.

Martin, K., \& Todorov, I. (2010). How will digital platforms be harnessed in 2010, and how will they change the way people interact with brands? Journal of Interactive Advertising, 10, 61-66.

Miller, M. (2009). YouTube for Business - Online Video Marketing for any Business. Indianapolis, IN: Que Publishing.

Nam, H., \& Kannan, P.K. (2014). The Informational Value of Social Tagging Networks. Journal of Marketing, Vol.78 (July 2014) 21-40.

Naylor, R.W., Lamberton, C.P., \& West, P.M. (2012). Beyond the "like" button: The impact of mere virtual presence on brand evaluations and purchase intentions in social media settings. Journal of Marketing, 76(6), 105-120. 
Oxford Economics. (2011). Economic Benefits from Air Transport in Germany. [online]. Oxford: Oxford Economics Ltd. Retrieved from:

http://www.benefitsofaviation.aero/Documents/Benefits-of-Aviation-Germany-2011.pdf

Saunders, M., Lewis, P., \& Thornhill, A. (2007). Research Methods for Business Students. 4th ed. Harlow: Pearson Education Limited.

Sekaran, U. And Bougie, R., 2010. Research Methods for Business - A Skill Building Approach. 5th ed. Chichester: John Wiley \& Sons Ltd.

Social Media Examiner. (2011). 2011 Social Media Marketing Industry Report - How Marketers are using Social Media to grow their business. [online]. Poway, CA: Social Media Examiner. Retrieved from: http://www.socialmediaexaminer.com/SocialMediaMarketingReport2011.pdf

Sue, V.M. and Ritter, L.A., 2011. Conducting Online Surveys. 2nd ed. Thousand Oaks: SAGE Publications Inc.

Parveen, F., Jaafar, N.I., \& Ainin, S. (2014) Social media usage and organizational performance: Reflections of Malaysian social media managers. Telematics and Information, 32 (2015) 67-78.

Safko, L. and Brake, D.K., 2009. The Social Media Bible: Tactics, Tools and Strategies for business success. Hoboken, NJ: John Wiley \& Sons.

Stumbleupon, 2012. 20 Million Stumblers!. [online]. San Francisco, CA: StumbleUpon. Retrieved from: http://www.stumbleupon.com/blog/20-million-stumblers/

Tourom. (2011). Social Media bei Airlines - Voruntersuchung zur TOUROM- Studie 2011: Social Media in der Reisebranche. Social Media for Airlines - Preliminary study on TOUROM- 
Study 2011: social media in the travel industry [online]. Frankfurt: Michael Faber Touristik Consulting. Retrieved from:

http://www.touristikconsulting.de/download/Studie_Social_Media_bei_Airlines.pdf

Tuten, T.L., 2008. Advertising 2.0: Social Media Marketing in a Web 2.0 World. Westport, CT: Praeger Publishers.

Valos, M., Polonsky, M.J., Movondo, F., \& Lipscomb, J. (2014). Senior marketers’ insights into the challenges of social media implementation in large organisations: assessing generic and electronic orientation models as potential solutions. Journal of Marketing Management ANNE help

Vespermann, J., \& Wittmer, A. (2010). Financial, ecological and managerial impacts of emission trading schemes: the case of Lufthansa. Business Strategy and the Environment. 20(3), 174-191.

Vollmer, C. and Precourt, G., 2008. Always on: Advertising, marketing and media in an era of consumer control. New York, NY: MacGraw- Hill.

Weinberg, T. (2009). The new community rules: Marketing on the social web. Sebastopol, CA: O’Reilly Media Inc.

Wilson, J., 2010. Essentials of Business Research - A Guide to Doing Your Research Project. London: SAGE Publications Ltd.

Winer, R.S. (2009). New Communication Approaches in Marketing: Issues and Research Directions. Journal of Interactive Marketing. 23(2),108-117.

Xinang, Z. and Gretzel, U., 2010. Role of social media in online travel information search.

Tourism Management. 31(2), pp.179-188. 
Ye, Q., Law, R., Gu, B., \& Chen, W. (2011). The influence of user- generated content on traveller behaviour: An empirical investigation on the effects of e-word-of- mouth to hotel online bookings. Computers in Human Behavior. 27(2), 634-639.

Zarella, D. (2010). The Social Media Marketing Book. Sebastopol, CA: O’Reilly Media Inc.

Zikmund, W.G. and Babin, B.J., 2007. Exploring Marketing Research. 9th ed. Mason, OH: Thomson South Western.

Zunke, K. (2012). Der zweite Frühling. Acquisa - Der direkte Weg zumKunden. The Second Spring. The direct route 60. (3), 42-43. 